\title{
The Correlation between Vocabulary Mastery and Their Ability in Writing Descriptive Text
}

\author{
Manggar Rizka Novitri ${ }^{*}$, Theresia Cicik Sophia Budiman ${ }^{2}$, Faiza Hawa $^{3}$ \\ ${ }^{1}$ Universitas PGRI Semarang \\ ${ }^{2,3}$ Universitas PGRI Semarang \\ ${ }^{1^{*} \text { rizkamanggar@gmail.com, }}{ }^{2}$ ciciksophia@upgris.ac.id, ${ }^{3}$ hawafaiza@gmail.com.
}

\begin{abstract}
This research is aimed to find out the correlation between two variables, vocabulary mastery as the objective variable $(\mathrm{X})$ and the writing ability in the descriptive text as the subjective variable (Y). The research method used is the quantitative method. The population used is 7 grade of SMPN 2 Pringapus with a total of 194 students. For the sample, only one class is used; there is $7 \mathrm{E}$ grade with 38 students. To analyze the instrument, there are two types of analysis, namely the technique of dividing students into three criteria and the analysis technique using Pearson Product Moment correlation. With the results, there is a significant correlation between vocabulary mastery and writing ability in writing descriptive text in 7 grade at SMPN 2 Pringapus, with the following results: With a degree of significance $5 \%$, the score of $\mathrm{r}$ table $\left(r_{t}\right)$ obtained is 0.329 , therefore, $r_{x y}>r_{t}(0.603>0.329)$, meanwhile, with a degree of significance of $1 \%$, the score of $\mathrm{rt}$ gained is 0.424 , therefore, $r_{x y}>r_{t}(0.603>0.424)$. The conclusion is $\mathrm{H}_{\mathrm{A}}$ is accepted.
\end{abstract}

Keywords: Vocabulary mastery, Writing ability, Descriptive text.

\section{INTRODUCTION}

A language is a tool for communicating in society, and each word has a meaning. Many countries use their language, one of them in Indonesia using "Bahasa Indonesia" as their language has been used to communicate. That dialect could be a communication tool that is utilized for expressing people's considerations and concepts (Jain \& Patel, 2008). Without language, the community cannot build a social activity, and without language, there will be no desired goal. Because language is so important, our government has designated English as a foreign language that students must comprehend. English is a universal language that is required for essential communication to compete in a global society. In schools, workplaces, and community politics, the English used has four skills, they are writing, listening, speaking, and reading. As claimed by Morrow in (Demirbaş 2013), the four abilities to listen, read, chat, and report make up receptive and productive abilities.

In addition to the four English skills, vocabulary is also essential. The most significant aspect of learning English is building a vocabulary. The four English abilities are all dependent on speech in English. It is necessary to begin teaching language to students at a young age to improve their ability to master English. As stated by Alqahtani in (Syartika 2020) that developing vocabulary is also as helpful in learning the meanings of new terms is emphasized in foreign language learning. Students can use speech in various ways, including watching movies, listening to music, reading books, etc. Good vocabulary mastery makes students fluent in speaking and reading. Besides that, vocabulary mastery can also make students fluent in writing and listening.

Writing skill is also very important. Writing ability is the most important thing; that is a complex and composing activity that can be delivered to the reader to obtain easily understood information. As stated by Ghazali \& Mohammad (Abdullah, 2019), to write an excellent piece of writing, a student must go through several processes and employ various techniques. To register, a student must have specialized abilities, such as the ability to form and organize thoughts about what they want to write about, as well as the ability to put those ideas into sentences, as stated by Sa'diyah in (Abdullah 2019). By writing, students can share thoughts, feelings, or whatever is on their minds. Writing ability is also very important 
for students to do school work in learning English. In addition, writing can also increase students' creativity in thinking and processing the right words.

Students' abilities in English include writing material that students must learn. At the same time, vocabulary is a supporting component that contains words. Writing has long been an element of the English curriculum (either of the four abilities) (Harmer Jeremy, 2004). Writing is an important English learning ability for students, while vocabulary is a supporting component in learning English. Writing has the types of text, namely, a descriptive text which is usually used to describe an object, place, or person. Then procedure text is used to give instructions to do something. Another reader is recount text is used to tell personal stories, and so on. In writing learning, they are required to pay attention to the rules of writing.

Descriptive text is a text that describes people, objects, or places where this text requires a variety of basic vocabulary so that students can explain an object quickly. In addition, descriptive text is studied by students in $7^{\text {th }}$ grade at the beginning of the semester.

So from the statements above, the researcher tried to find the relationship between two skills, especially in the students' understanding of the English language and their writing ability. The researcher also tried to determine how students improve their understanding.

About the study conducted, the researchers found out the previous study about "The Correlation Between Vocabulary Mastery and Reading Ability on Narrative Text at The Second Year Students of SMP N 3 Kampar", which Yani (2013). The design of the research is correlated by applying quantitative analysis. The findings show that high and low reading abilities are related to high and low English vocabulary mastery that $\mathrm{r}_{\mathrm{xy}}$ was higher than $\mathrm{r}_{\text {table }}$ at $5 \%=0.325$ and $1 \%=0.418$. The correlation score is 1.19 when compared $t_{0}$ and $r_{t}$. (Yani, 2013)

Zhihong Bai at the Shanxi Normal University, China (2018) researched English Vocabulary Learning Strategies. In this research, the researcher was concerned with the problems with vocabulary mastery and using a questionnaire survey. There are two types of elements that impact the learner's vocabulary learning, and they are individual and social environment factors. In the personal aspect, if students focus on vocabulary, they use more cognitive and memory strategies. Suppose a focus on vocabulary function useless cognitive strategies but memory use more communicative approach. Meanwhile, in the social environment, factors affect the learner's processes.

Student $1=72 \%$, Student $2=97 \%$, Student $3=90 \%$, Student $4=66 \%$, Student $5=90 \%$, Student $6=$ $76 \%$, Student $7=62 \%$. (Klimova, 2014)

\section{LITERATUR REVIEW}

\section{Vocabulary}

The study of vocabulary is intimately linked to the acquisition of a language. In communication, vocabulary aids speakers in communicating their thoughts, ideas, and feelings. Because vocabulary impacts four language abilities: listening, speaking, reading, and writing, it is the most significant language component. Vocabulary is an essential component for learners since individuals who want to grasp a language must master vocabulary.

The importance of vocabulary cannot be overstated. The students to convey various expressions of their opinions and in the form of sentences. In a sentence, there is a meaning that is constructed through words. Learning a language begins with the vocabulary used, as speech contains the grammar utilized when talking.

Good vocabulary mastery is one of the main elements for better communication. Students who know a lot of words will be better listeners, writers, speakers, and readers. Students need to improve their vocabulary skills to help achieve success in school.

According to (Penny, 1996) teachers, when teaching vocabulary, need to notice the six-item below:

1) Form (pronunciation and spelling): students can know the sound form of a word (pronunciation) and the form of a word (spelling). 2) Grammar: if the general grammar rules do not adequately address the situation, a new grammar item should be taught. 3) Collocation: the distinctive collocation of the item is 
another aspect that determines whether a given combination sounds "correct" or "incorrect" in a given context. 4) Aspects of meaning (1): denotation, connotation, and appropriateness: The denotation of a word is essentially what it means in everyday life; dictionaries typically include this type of definition. 5) Aspects of meaning (2): meaning relationships teaching can also benefit from understanding how one item's meaning links to that of others. 6) Word formation vocabulary items can often be broken down into component "pieces," whether single words or multi-word phrases. Another valuable piece of knowledge - possibly mainly for more sophisticated users - is how these components are together.

\section{Writing Ability}

Writing abilities are difficult to teach since they require knowledge not only in terms of grammatical and theoretical procedures and also in terms of conceptual and judging features. It's essential to note that writing is a method, not an outcome. Writing, reading, listening, and speaking are the four abilities given to junior high school students when learning English. The four most challenging skill is writing because they require mastery such as word selection, structure, and writing mechanic. The thing that most support writing skill is students' vocabulary mastery they should be used. According to (Kate, 2001) there are three purposes of writing: 1) To entertain: writing to consider is an imaginary form of writing. The writer was writing with creative ideas that can make the reader touched. 2) To inform: writing to inform contains information about a place, object, or event. Usually can be found in articles, newspapers, or magazines. 3) To persuade: writing to persuade is the writer aims to convey something in the form of facts or data with the intention that readers can follow up.

The highly significant it is for this reason that writing is taught. That it is as vital as speaking, listening, and reading in terms of primary language. Using writings from English Foreign Languages, the students can express messages to readers who travel through time and space. In theory, the objective of writing is to explain ideas and provide the reader with notice. The writer, on the other hand, must consider the formal qualities as well — correct spelling and grammar, such as neat handwriting. There are three approaches by Penny, 1996 as below: 1) As manners: The activity of writing is commonly utilized in foreign language classes as a suitable way to engage with various components of the language other than the writing itself. Take notes on vocabulary, copy grammar rules, read responses, and take written tests as examples. 2) As an end: As a micro-level written representation of certain macro-level practices on the emphasis is on substance or structure at the macro level. (handwriting or typing, spelling, and punctuation). 3) As both means and end: The following activity blends deliberate and original writing with the learning or practising of a learning activity or information. For instance, written answers upon reading scathing newspaper articles (combine writing with reading).

\section{Descriptive Text}

The features of a person or an object are described in this writing. Its purpose is to reveal and express a particular person, location, or entity. Related to (Oshima, A \& Hogue, 2007), if the reader can describe an object, place, or person, it can be said to be a good description. The process of describing anything in writing is known as description. Words are used to produce visual images and sensory experiences. Reports are typically used to describe something or someone to the reader or perceive things from the author's perspective. The goal of descriptive text is to demonstrate the facts found in a text so that the readers can read and describe it. My cat, for example, has four legs.

There is two generic structure of the descriptive text. 1) Identification: the purpose of this part, which appears in the opening paragraph, is to identify an object that will be discussed. The objective of identification is to introduce the reader to the object that will be detailed before going into greater detail in the following paragraph. 2) Description: Description that includes the nature of a thing that was introduced to the reader in the first paragraph can be found in the second paragraph and so on.

After the students understand the generic structure, students should know about language features and the features of descriptive text. 1) Descriptive text often use the noun such us specific participant: my house, my cat, Parangtritis beach. The description also often uses adjectives to describe the noun: beautiful girl, brilliant student, big house. 2) Descriptive language is frequently written in the simple present tense and provides facts. For example, he got an accident, and I have 12 cats, etc. 3) Descriptive text uses the verb; the verb shows activity in the text, such as walking, eating, cooking, etc. 


\section{METHOD}

In this research, the sort of research is a correlation with a quantitative technique. Correlation research is an investigation into the link between two or more related variables. A variable that causes or impacts the order variables is known as an independent variable. The independent variable affects the dependent variable (Marczyk, 1964). Students' vocabulary competency is the independent variable in this study, while their writing ability in the descriptive text is the dependent variable. In this research, the researcher used a quantitative approach based on the measurement and quantity amount.

a. Population and Sample

Based on Sugiyono, a population is a generalized area made up of persons or items with specified attributes or characteristics that are chosen for investigation and findings by researchers (Sugiono, 2017). The researcher has researched SMPN 2 Priapus. There are 194 students in the overall population, divided into five classes.

The participants in this study are 7th-grade students in the first semester at SMPN 2 Pringapus. The researcher selects 38 participants from the VII E class to participate in the research.

b. Instrument of the Research

1) The Vocabulary Test

The first test is a test that was carried out by students is a test to determine students' vocabulary mastery by using multiple-choice provided by the researcher. The researcher gives 25 multiple choice questions about vocabulary; each number has four choices (A), (B), (C), (D). There is a formula is how to find out students' scores is:

Test Score $=\frac{\text { Correct answers }}{\text { Total item of questions }} \times 100$

The researcher used the criteria from the evaluation standard for the students' scores to determine their performance on the vocabulary test.

Table 1. The scoring of vocabulary test

\begin{tabular}{llll}
\hline No & Interval & F & Criteria \\
\hline 1. & $86-100$ & 7 & Excellent \\
\hline 2. & $66-85$ & 23 & Good \\
\hline 3. & $46-65$ & 8 & Enough \\
\hline 4. & $26-45$ & 0 & Poor \\
\hline 5. & Under 25 & 0 & Failed \\
\hline
\end{tabular}

2) The Writing Test

The researcher gave the students a worksheet about text by providing a worksheet in an essay. The descriptive text of the writing test is used to evaluate students' abilities to produce explanatory material. There are three different topics: 1) My daily activity, 2) My hobby, 3) My favourite animal/thing.

The scale is shown here according to Heaton (1988:146). In a rating scale, there is a scale order. The following is the rating scale:

Table 2. The scoring of writing test

\begin{tabular}{lcll}
\hline No & Aspect & Scoring scale & \multicolumn{1}{c}{ Description } \\
\hline 1. & Content & $30-27$ & Excellent to very good \\
\hline & & $26-22$ & Good to average \\
\hline & & $21-17$ & Fair to poor \\
\hline 2. & Organization & $20-18$ & Very poor \\
\hline & & $17-14$ & Good to average \\
\hline
\end{tabular}




\begin{tabular}{|c|c|c|c|}
\hline & & $13-10$ & Fair to poor \\
\hline & & $9-7$ & Very poor \\
\hline \multirow[t]{4}{*}{3.} & Vocabulary & $20-18$ & Excellent to very good \\
\hline & & $17-14$ & Good to average \\
\hline & & $13-10$ & Fair to poor \\
\hline & & $9-7$ & Very poor \\
\hline \multirow[t]{4}{*}{4.} & Language use & $25-22$ & Excellent to very good \\
\hline & & $21-19$ & Good to average \\
\hline & & $17-11$ & Fair to poor \\
\hline & & $10-5$ & Very poor \\
\hline \multirow[t]{4}{*}{5.} & Mechanics & 5 & Excellent to very good \\
\hline & & 4 & Good to average \\
\hline & & 3 & Fair to poor \\
\hline & & 2 & Very poor \\
\hline
\end{tabular}

3) Significant correlation between vocabulary mastery and students' ability in writing.

The researcher uses Arikunto's product-moment formula to see a link between vocabulary competence and writing abilities. The procedure for calculating the correlation can be found in the section on the data collection method.

c. The Collecting Data

This research was conducted at SMPN 2 Pringapus. The researcher chooses class VII E for the researcher's study. The following procedures were used to collect the data: 1) The researcher gave a test of vocabulary mastery which consisted of 25 questions for 38 students. 2) To find out the results of vocabulary mastery, the student's answer sheet for each correct point was given 4 points with a total of 25 questions that the highest score is 100. 3) For the written test, students wrote a text description on a blank worksheet. 4) Students must complete a descriptive text for the writing test prepared by the researchers for 38 students. To find out their abilities, the researcher examined students' worksheets by reading one by one.

In determining the value of this writing, the researcher used the scale proposed by Heaton (1988:146); there is 5 level of the scale. The grading scale measures students writing skills, especially in organization, content, grammar, mechanic, and vocabulary. They have already stated in the research instrument.

d. Data Analysis Technique

In this research, the writer uses two techniques to analyze data. They are:

1) The technique is used to categorize the students into three criteria (Sudijono, 2006). They are up a rank (good), middle-rank (enough), and bottom rank (low). The formula is:

a. $\mathrm{M} x+1 \mathrm{SD} x$

$\mathrm{M} x-1 \mathrm{SD} x$

Notes:

$\mathrm{M} x$ : mean of English vocabulary mastery (X)

SDx: standard deviation of vocabulary mastery

b. $\mathrm{M} y+1 \mathrm{SD} y$

$\mathrm{M} y-1 \mathrm{SD} y$

Notes:

M y: mean of writing (Y)

SDy: standard deviation of writing ability

2) Product moment correlation was employed to examine the data, and the formula is as follows: 


$$
r_{x y}=\frac{N \sum X Y-\left(\sum X\right)\left(\sum Y\right)}{\sqrt{\left\{N \sum X^{2}-\left(\sum X\right)^{2}\right\}\left\{N \sum Y^{2}-\left(\sum Y\right)^{2}\right\}}}
$$

Notes:

$r_{x y}:$ Correlation coefficient

$N$ : The sum number of people who took part in this study

$\sum x y$ : The sum vocabulary score of the students

$\sum y$ : The sum score of students' writing text

$\sum x$ : On a variety of measures, the sum of students' vocabulary proficiency and writing text skills.

$\sum x^{2}:$ The sum score for each student's vocabulary mastery square.

$\sum y^{2}$ : The sum square score of a student's descriptive text writing skill.

Table 3. The Orientation of Giving Interpretation on the Coefficient Correlation

Interval coefficient The level of correlation

\begin{tabular}{cc}
\hline $0.00-0.199$ & Very low \\
\hline $0.20-0.399$ & Low \\
\hline $0.40-0.599$ & Medium \\
\hline $0.60-0.799$ & High \\
\hline $0.80-1.00$ & Very high \\
\hline
\end{tabular}

\section{RESULTS AND DISCUSSION}

The information gathered as part of the research is described in the data. The researcher concluded the report by giving tests to seventh-grade students at SMPN 2 Pringapus. As a participant, the researcher used the scores of 38 students. The objective test was a written descriptive text test, while the subjective text was a vocabulary mastery test. Multiple choice was the format of the accurate test. The student's mastery of the form, meaning and application of vocabulary was emphasized in the trial. There were 25 different English vocabulary items in total. The total score of the English vocabulary test was 100 score.

Test Score $=\frac{\text { Correct answers }}{\text { Total item of questions }} \times 100$

The following is a list of vocabulary test results and descriptive text writing test results:

Table 4. The score of vocabulary mastery $(\mathrm{X})$

\begin{tabular}{cll}
\hline No. & Participants & X \\
\hline 1 & Student 1 & 76 \\
\hline 2 & Student 2 & 68 \\
\hline 3 & Student 3 & 68 \\
\hline 4 & Student 4 & 60 \\
\hline 5 & Student 5 & 76 \\
\hline 6 & Student 6 & 84 \\
\hline 7 & Student 7 & 76 \\
\hline 8 & Student 8 & 88 \\
\hline 9 & Student 9 & 88 \\
\hline 10 & Student 10 & 64 \\
\hline 11 & Student 11 & 68 \\
\hline 12 & Student 12 & 60 \\
\hline 13 & Student 13
\end{tabular}




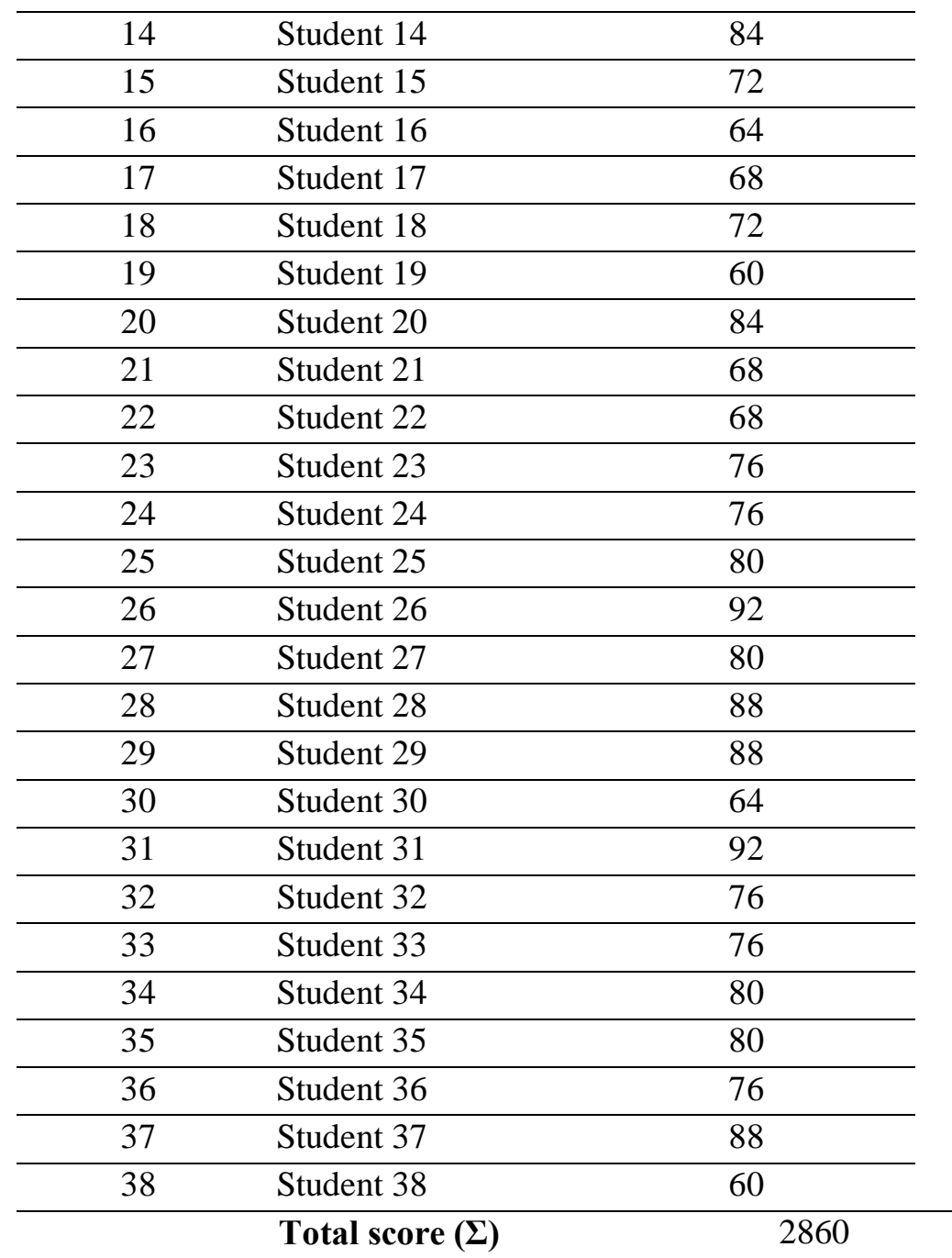

From the data above, that is the $\sum x=2860$, after the researcher, calculated the vocabulary test scores of 38 students.

In the writing test assessment, the researcher scored based on Heaton's calculation presented in Table 2. The results of the descriptive text writing test are shown below:

Table 5. The score of writing descriptive text-ability (Y)

\begin{tabular}{cll}
\hline No. & Participants & Y \\
\hline 1 & Student 1 & 67 \\
\hline 2 & Student 2 & 63 \\
\hline 3 & Student 3 & 64 \\
\hline 4 & Student 4 & 58 \\
\hline 5 & Student 5 & 72 \\
\hline 6 & Student 6 & 84 \\
\hline 7 & Student 7 & 73 \\
\hline 8 & Student 8 & 73 \\
\hline 9 & Student 9 & 80 \\
\hline 10 & Student 10 & 63 \\
\hline 11 & Student 11 & 64 \\
\hline 12 & Student 12 & 75 \\
\hline 13 & Student 13 & 65 \\
\hline 14 & Student 14 & 84 \\
\hline 15 & Student 15 & 67 \\
\hline
\end{tabular}




\begin{tabular}{|c|c|c|}
\hline 16 & Student 16 & 69 \\
\hline 17 & Student 17 & 77 \\
\hline 18 & Student 18 & 75 \\
\hline 19 & Student 19 & 69 \\
\hline 20 & Student 20 & 74 \\
\hline 21 & Student 21 & 66 \\
\hline 22 & Student 22 & 74 \\
\hline 23 & Student 23 & 73 \\
\hline 24 & Student 24 & 80 \\
\hline 25 & Student 25 & 78 \\
\hline 26 & Student 26 & 72 \\
\hline 27 & Student 27 & 77 \\
\hline 28 & Student 28 & 67 \\
\hline 29 & Student 29 & 80 \\
\hline 30 & Student 30 & 67 \\
\hline 31 & Student 31 & 88 \\
\hline 32 & Student 32 & 77 \\
\hline 33 & Student 33 & 65 \\
\hline 34 & Student 34 & 60 \\
\hline 35 & Student 35 & 79 \\
\hline 36 & Student 36 & 68 \\
\hline 37 & Student 37 & 82 \\
\hline 38 & Student 38 & 72 \\
\hline & tal score $(\Sigma)$ & 2741 \\
\hline
\end{tabular}

The $\sum y=2741$, after the researcher, calculated the vocabulary test scores of 38 students. After the scores of the two variables are known, the researcher continues to find out the analysis of the Level of Students' vocabulary mastery. The researcher should analyze the data in this step, including calculating the mean, standard deviation, maximum score, and minimum score on the vocabulary mastery test. The following is a description of the calculation.

Table 6. The analysis score of the vocabulary mastery test

\begin{tabular}{cccccc}
\hline $\boldsymbol{X}$ & $\boldsymbol{f}$ & $\boldsymbol{f} \boldsymbol{X}$ & $(\boldsymbol{X}-\overline{\boldsymbol{X}})$ & $(\boldsymbol{X}-\overline{\boldsymbol{X}})^{\mathbf{2}}$ & $\boldsymbol{f}(\boldsymbol{X}-\overline{\boldsymbol{X}})^{\mathbf{2}}$ \\
\hline 92 & 2 & 184 & 18 & 324 & 578 \\
\hline 88 & 5 & 440 & 14 & 196 & 845 \\
\hline 84 & 3 & 252 & 10 & 100 & 243 \\
\hline 80 & 5 & 400 & 6 & 36 & 125 \\
\hline 76 & 6 & 456 & 2 & 4 & 1 \\
\hline 72 & 5 & 360 & -2 & 4 & 45 \\
\hline 68 & 4 & 272 & -6 & 36 & 196 \\
\hline 64 & 3 & 192 & -10 & 100 & 1125 \\
\hline 60 & 5 & 300 & -14 & 196 & $\boldsymbol{\Sigma} \boldsymbol{f}(\boldsymbol{X}-\overline{\boldsymbol{X}})^{\mathbf{2}}=$ \\
\hline \multirow{2}{*}{ Total } & $\mathbf{N}=\mathbf{3 8}$ & $\mathbf{2 8 5 6}$ & - & - & $\mathbf{3 5 2 1}$ \\
\hline
\end{tabular}

$\mathrm{X}=$ Vocabulary mastery Test's score

$f=$ Frequency of the score 
To know the Mean and Standard Deviation of vocabulary mastery test's score, the researcher uses the following formula:

$$
\begin{aligned}
\text { Mean }(\text { or } X) & =\Sigma \frac{f X}{N} \\
& =\frac{3521}{38} \\
& =75,157 \approx 75
\end{aligned}
$$

Standard deviation $(\sigma)=\sqrt{\sum \frac{f X^{2}}{N}}$

$$
\begin{aligned}
& =\sqrt{\frac{3521}{38}} \\
& =\sqrt{92,657894} \\
& =9,625 \approx 100
\end{aligned}
$$

After determining Mean and standard deviation, then the writer determines the interval score of each

\begin{tabular}{|c|c|c|c|c|}
\hline No & Interval & $\mathbf{F}$ & Criteria & Percentage \\
\hline 1. & $86-100$ & 7 & Excellent & $19 \%$ \\
\hline 2. & $66-85$ & 23 & Good & $60 \%$ \\
\hline 3. & $46-65$ & 8 & Enough & $21 \%$ \\
\hline 4. & $26-45$ & 0 & Poor & $0 \%$ \\
\hline 5. & Under 25 & 0 & Failed & $0 \%$ \\
\hline
\end{tabular}
criteria, the calculations are as follows:

$$
\begin{aligned}
\text { Top up of vocabulary score } & =\mathrm{M} x+1 \mathrm{SD} x \\
& =74+1.9 \\
& =74+9 \\
& =83 \\
\text { Bottom of vocabulary score } & =\mathrm{M} x-1 \mathrm{SD} x \\
& =74-1.9 \\
& =74-9 \\
& =65
\end{aligned}
$$

From the table statical above, the level of students' vocabulary mastery can be measured as in the table below:

Table 7. The analysis of Level measurement of Students' Vocabulary Mastery Test

(Depdiknas, 2004)

After the result above, it is known that the scores of the seventh-grade vocabulary test at SMPN 2 Pringapus are not only in one interval but in various intervals. There are seven students or $19 \%$ who are in very good categorized with a break of 86 - 100 scores, 23 students or $60 \%$ are in well classified with an interval of 66 - 85 scores, eight students or $21 \%$ who are in enough categorized with a break of 46 65 scores. From this analysis, it can be concluded that the vocabulary mastery of class VII at SMPN 2 Pringapus is good.

The Analysis of Level of The Students' Written Test of Descriptive Text

To analyze writing test data, it takes steps in assessing. This analysis is also to determine the students' ability to write a descriptive text. The following data analysis to determine the points are:

Table 8. The analysis score of the students' written test of descriptive text

\begin{tabular}{cccccc}
\hline $\boldsymbol{Y}$ & $\boldsymbol{f}$ & $\boldsymbol{f} \boldsymbol{Y}$ & $(\boldsymbol{Y}-\overline{\boldsymbol{Y}})$ & $(\boldsymbol{Y}-\overline{\boldsymbol{Y}})^{\mathbf{2}}$ & $\boldsymbol{f}(\boldsymbol{Y}-\overline{\boldsymbol{Y}})^{\mathbf{2}}$ \\
\hline 58 & 1 & 58 & -9 & 81 & 81 \\
\hline 60 & 1 & 60 & -7 & 49 & 49 \\
\hline
\end{tabular}




\begin{tabular}{cccccc}
\hline 63 & 3 & 63 & -4 & 16 & 16 \\
\hline 64 & 2 & 128 & -3 & 9 & 18 \\
\hline 65 & 2 & 130 & -2 & 4 & 8 \\
\hline 66 & 1 & 66 & -1 & 1 & 1 \\
\hline 67 & 4 & 268 & 0 & 0 & 4 \\
\hline 69 & 1 & 69 & 2 & 4 & 100 \\
\hline 72 & 3 & 288 & 5 & 25 & 72 \\
\hline 73 & 2 & 146 & 6 & 36 & 98 \\
\hline 74 & 2 & 148 & 7 & 49 & 200 \\
\hline 75 & 2 & 225 & 8 & 64 & 242 \\
\hline 77 & 2 & 154 & 10 & 100 & 144 \\
\hline 78 & 2 & 156 & 11 & 121 & 338 \\
\hline 79 & 1 & 79 & 12 & 144 & 867 \\
\hline 80 & 2 & 160 & 13 & 169 & $\mathbf{\Sigma} \boldsymbol{f}(\boldsymbol{Y}-\overline{\boldsymbol{Y}})^{\mathbf{2}}=$ \\
\hline 84 & 3 & 252 & 17 & 289 & 2871 \\
\hline 88 & 1 & 88 & 21 & 441 & - \\
\hline \multirow{2}{*}{ Total } & $\mathbf{N}=38$ & 2538 & - & & \\
\hline
\end{tabular}

\section{$\mathrm{Y}=$ Written test of descriptive text score}

\section{$f=$ Frequency of the score}

To know the Mean and Standard Deviation of written test of descriptive text score, the researcher uses the following formula:

$$
\begin{aligned}
\text { Mean }(\text { or } Y) & =\Sigma \frac{f Y}{N} \\
& =\frac{2538}{38} \\
& =66,7894 \approx 67
\end{aligned}
$$

Standard deviation $(\sigma)=\sqrt{\sum \frac{f Y^{2}}{N}}$

$$
\begin{aligned}
& =\sqrt{\frac{2871}{38}} \\
& =\sqrt{75,552631} \\
& =8,6921 \approx 9
\end{aligned}
$$

After determining the Mean and standard deviation, the researcher determines the top up and bottom. This means knowing the limits of the legal category of ability to write descriptive text scores.

Top up of writing score $=\mathrm{M} y+1 \mathrm{SD} y$

$$
\begin{aligned}
& =67+1.9 \\
& =67+9 \\
& =76
\end{aligned}
$$

Bottom of writing score $=\mathrm{M} y-1 \mathrm{SD} y$

$$
\begin{aligned}
& =67-1.9 \\
& =67-9 \\
& =58
\end{aligned}
$$

The writing ability of the seventh-grade students of SMPN 2 Pringapus can be determined by accumulating the data above. The analysis is:

Table 9. The Analysis of Level Measurement of Students' Writing Ability of Descriptive Text

\begin{tabular}{lrrrr}
\hline No & Interval & F & Criteria & Percentage \\
\hline 1. & $86-100$ & 1 & Excellent & $3 \%$ \\
\hline
\end{tabular}




\begin{tabular}{llcll}
\hline 2. & $66-85$ & 30 & Good & $79 \%$ \\
\hline 3. & $46-65$ & 7 & Enough & $18 \%$ \\
\hline 4. & $26-45$ & 0 & Poor & $0 \%$ \\
\hline 5. & Under 25 & 0 & Failed & $0 \%$
\end{tabular}

(Depdiknas, 2004)

After the result above, it is known that the scores of the seventh-grade vocabulary test at SMPN 2 Pringapus are not only in one interval but in various intervals. There are one student or $3 \%$ who are in very good categorized with a break of 86 - 100 scores, 30 students or $79 \%$ are in well classified with an interval of 66 - 85 scores, seven students or $18 \%$ who are in enough categorized with a break of $46-65$ scores. From this analysis, it can be concluded that the vocabulary mastery of class VII at SMPN 2 Pringapus is good.

The Correlation Analysis Between The Students Vocabulary Mastery and Their Writing Ability of Descriptive Text

After calculating the total score of the research variables, vocabulary mastery (X), and the ability to write descriptive text, the correlation coefficient between the two variables is calculated to investigate the relationship between the two variables (Y). Pearson Product Moment is used to analyze this. $r_{x y}$ Represents the Pearson Product Moment correlation. To get the score of $r_{x y}$, firstly the scores of $\sum x y, \sum x^{2}, \sum y^{2}$ are looking for the results as follows: $\sum X=2860, \sum Y=2741, \sum X Y=207828$, $\sum X^{2}=218608, \sum Y^{2}=199635$

$r_{x y}=\frac{N \Sigma X Y-(\Sigma X)(\Sigma Y)}{\sqrt{\left\{N \Sigma X^{2}-(\Sigma X)^{2}\right\}\left\{N \Sigma Y^{2}-(\Sigma Y)^{2}\right\}}}$

$r_{x y}=\frac{38(207828)-(2860)(2741)}{\sqrt{38(218608)-(2860)^{2}\left(38(199635)-(2741)^{2}\right.}}$

$r_{x y}=\frac{7897464-7839260}{\sqrt{(8307104-8179600)(7586130-7513081)}}$

$r_{x y}=\frac{58204}{\sqrt{(127504)(73049)}}$

$r_{x y}=\frac{58204}{\sqrt{9314039696}}$

$r_{x y}=\frac{58204}{96509,27259}$

$r_{x y}=0,603$

This is the outcome of the calculation using data from variables $\mathrm{X}$ and $\mathrm{Y}$. After obtaining the score, With degrees of the significance of $5 \%$ and $1 \%$, it is compared to the score of the $\mathrm{r}$ table (rt). as follows:

$$
\begin{aligned}
\mathrm{df} & =\mathrm{N}-\mathrm{nr} \\
& =38-2 \\
& =36
\end{aligned}
$$

Notes:

df $\quad=$ Degree of freedom

$\mathrm{N} \quad=$ Number of cases

$\mathrm{nr} \quad=$ Number of research variables

Based on the research findings of this study, the calculation of $r_{x y}$ It is 0,603 , and the score $\mathrm{df}$ is 36 . Then, the score $r_{x y}$ is compared with the degree of significance $5 \%$, which shows that with $\mathrm{df}=36$, the $\mathrm{rt}$ score which is obtained is 0,329 , therefore, $r_{x y}>r t$. Meanwhile, the score $r_{x y}$ is compared with the degree of significance $1 \%$, which shows that with the $\mathrm{df}=36$, the score which is obtained is 0,424 , 
therefore, $r_{x y}>r t$. It caused the $\mathrm{H}_{\mathrm{o}}$ (Null Hypothesis) to be rejected, and $\mathrm{H}_{\mathrm{A}}$ (Alternative Hypothesis) was accepted. It means there is no significant correlation between students' vocabulary mastery and their writing ability of descriptive text in the case research of the $7^{\text {th }}$-grade students of SMPN 2 Pringapus in academic 2021/2022. The writer consulted with the criteria of Arikunto to know the degree or the level of the correlation as follows:

Table 10. The Orientation of Giving Interpretation on the Coefficient Correlation Interval coefficient The level of correlation

\begin{tabular}{cc}
\hline $0.00-0.199$ & Very low \\
\hline $0.20-0.399$ & Low \\
\hline $0.40-0.599$ & Medium \\
\hline $0.60-0.799$ & High \\
\hline $0.80-1.00$ & Very high
\end{tabular}

(Arikunto, n.d.)

According to the computation, it shows that the score of $r_{x y}=0,603$. The categorized by using coefficient correlation criteria above. It shows that 0,603 is classified interval $0,600-0,800$ in the correlation indexes is a high correlation.

\section{Hypothesis}

This research is to answer the following hypotheses:

a Null hypothesis $\left(\mathrm{H}_{\mathrm{o}}\right)$ : there is no significant correlation between students' vocabulary mastery and their writing ability of descriptive text.

b Alternative hypothesis $\left(\mathrm{H}_{\mathrm{A}}\right)$ : there is no significant correlation between students' vocabulary mastery and their writing ability of descriptive text.

The statistical hypotheses are as follows:

1) $\mathrm{H}_{\mathrm{o}}: \rho=0$ or if $r_{x y}<r t, \mathrm{H}_{\mathrm{o}}$ is accepted, and $\mathrm{H}_{\mathrm{A}}$ is rejected;

2) $\mathrm{H}_{\mathrm{A}}: \rho \neq 0$ or if $r_{x y}>r t, \mathrm{H}_{\mathrm{A}}$ is accepted, and $\mathrm{H}_{\mathrm{o}}$ is rejected.

\section{CONCLUSION}

From the analysis results above, the researcher concludes a relationship between vocabulary mastery and writing ability. It can be seen that the hypothesis shows that $r_{x y}$ is greater than $r r_{t}$, it shows that $\mathrm{H}_{\mathrm{A}}$ is accepted.

The researcher found that the relationship between vocabulary and writing cannot be separated; these variables influence each other.

Based on the previous discussion and result of the research above, the researcher concludes that:

1) The average score of $7^{\text {th }}$ grade English vocabulary mastery at SMPN 2 Pringapus in 2020/2021 is good. With an interval value of 66 - 85 with 23 of 38 students or $60 \%$. This can be categorized as good.

2) The average score of $7^{\text {th }}$-grade writing ability of descriptive text at SMPN 2 Pringapus in 2020/2021 is good. With an interval value of 66 - 85 with 30 of 38 students or $79 \%$. This can be categorized as good.

3) Yes, there is a significant correlation between students' vocabulary mastery and their writing ability in descriptive text in the $7^{\text {th }}$ grade at SMPN 2 Priapus. The correlation score is 0.603 based on the results of multiplication with the product-moment correlation pattern. The correlation index of 0.600 - 0.800 has shown this. The mastery of language is related to the level of writing abilities, it can be concluded. 


\section{REFERENCES}

. (2004). kerangka dasar kurikulum. Jakarta: Depdiknas.

Abdullah, Y. (2019). The Use of Picture in Improving Students' Writing. Modern Journal of Language Teaching Methods, 4(5), 1-8. https://doi.org/10.26655/mjltm.2019.4.5

Arikunto, S. (n.d.). Prosedur Penelitian Suatu Pendekatan Praktik. Jakarta: Rineka Cipta.

Demirbaş. (2013). Performance Differences between ELT Freshmen's Receptive and Productive Skills. 9(1), 107-127. Retrieved from http://www.jlls.org/vol9no1/107-127.pdf

Harmer Jeremy. (2004). How to teach writing. Essex: Pearson Education.

Jain \& Patel. (2008). English Language Teaching. Jaipur: Sunrise Publishers \& Distributors.

Kate, G. (2001). Writing from Start to Finish: A Six-Step Guide. Sidney: Griffin Press. Retrieved from http://alexabe.pbworks.com/f/Writing+from+Start+to+Finish.pdf

Klimova, B. F. (2014). Approaches to the Teaching of Writing Skills. Procedia - Social and Behavioral Sciences, 112, 147-151. Retrieved from http://dx.doi.org/10.1016/j.sbspro.2014.01.1149

Marczyk, G. (1964). Essentials of Research Design and Methodology. New Jersey: John Willey $\&$ Sons, inc.

Oshima, A \& Hogue, A. (2007). Writing Academic English (Third). New York: Addison Wesley Longman.

Penny, U. (1996). A Course in Language Teaching. United Kingdom: Cambridge University Press.

Sudijono. (2006). Pengantar Statistik Pendidikan. PT Raja Grafindo Persada.

Sugiono. (2017). Metode Penelitian Pendidikan: Pendekatan Kuantitatif, Kualitatif, dan R\&D. Alfabeta CV.

Syartika, W. (2020). Correlation Between Students' Writing Ability in Descriptive Text and Their Vocabulary Mastery. Curricula: Journal of Teaching and Learning, 5(1), 39-48. https://doi.org/10.22216/jcc.2020.v5il.1539

Yani, E. (2013). THE CORRELATION BETWEEN VOCABULARY MASTERY AND READING ABILITY ON NARRATIVE TEXT AT THE SECOND-YEAR STUDENTS OF SMP N 3 KAMPAR. UIN Suska Riau. 